\begin{abstract}
Grażyna Dolińska-Zygmunt
Agnieszka Nomejko

Uniwersytet Wrocławski, Wydział Nauk Historycznych i Pedagogicznych

Instytut Psychologii
\end{abstract}

\title{
Satysfakcja seksualna i samoocena a poczucie jakości życia
}

\section{Wstęp}

Satysfakcja seksualna silnie wiąże się z jakością życia i szczęściem (R o se n, Bachmann, 2008). Aktywność seksualna może przysparzać wielu korzyści, wśród których znajdują się nie tylko spełnione cele reprodukcyjne. Służy ona również utrzymaniu zadowolenia ze związku i dostarczaniu przyjemności emocjonalnej, psychologicznej i fizycznej (B a n croft, 2009). Z badań A. Gulczyńskiej i B. Jankowiak (2006) wynika, iż osoby aktywne seksualnie mają wyższy poziom koherencji (zaradności i sensowności). Zarówno utrzymujące się niedyspozycje seksualne, jak i chwilowe zaburzenia w tej sferze mogą być przyczyną stresu, frustracji, lęków czy depresji. Mogą także negatywnie wpływać na związek i inne obszary życia (A r r i n g to $n$ i in., 2004). Badania przeprowadzone przez Kopenhaskie Centrum Badań nad Jakością Życia (The Quality-of-Life Research Center, Copenhagen) na populacji 2400 osób, w przedziale wiekowym 18-88, wykazały, iż osoby z dysfunkcjami seksualnymi cechuje poziom jakości życia do $20 \%$ niższy niż u osób zdrowych (V e n te g odt, 1998).

W licznych badaniach wykazano związek samooceny $\mathrm{z}$ wieloma wymiarami życia m. in. zdrowiem, związkami interpersonalnymi, osiagnięciami zawodowymi czy też ogólnym zadowoleniem z życia (L i i in., 2010; C a m e r o n i in., 2010; Salmela-Aro, Nurmi, 2007; Baumeister i in., 2003). Ponadto wysoka samoocena jest predyktorem długowieczności (B a umeister i in., 2003) i ważnym elementem związanym z opanowywaniem trwogi śmiertelności (S. Solomon, J. Greenberg, T. Pyszczyński, 1991, za: Doliński, K o fta, 2006). Osoby o samoocenie niskiej określane są jako bardziej depresyjne, częściej okazujące smutek, przygnębienie i rozczarowanie. Przeżywają one silniej emocje negatywne i mają trudności w przeżywaniu emocji pozytywnych. Z niskim poczuciem własnej wartości współwystępują również objawy psychosomatyczne - im niższa samoocena, tym ich więcej (M. H. Kernis, B. D. Granemann, Barclay, 1989, za: W oj c i s z k e, 2006). 
Wyniki badań dowodzą, że zburzenia w sferze seksualnej - szczególnie anorgazmia i zaburzenia wzwodu - pozostają w związku z niską samooceną, a wysoka samoocena współwystępuje $\mathrm{z}$ wyższą satysfakcją z życia seksualnego i brakiem zahamowań w tym obszarze (B a n c r o ft, 2009; B a u m e is ter i in. 2003; Leiblum, Rosen, 2005; Narvaez-Rehbein i in., 2006). Osoby o niskiej samoocenie uważają się za mniej atrakcyjne, co znacząco utrudnia im nawiązywanie bliskich kontaktów. Cześciej doznają one nieodwzajemnionej miłości i lęku przed odrzuceniem (B a u meister i in., 2003), co może utrudniać poznanie potencjalnego partnera seksualnego. $\mathrm{Z}$ kolei $\mathrm{w}$ związku problemy z poczuciem wartości jednego z partnerów prowadzą do zmniejszenia poziomu pożądania u drugiej osoby. Pozytywny obraz własnego ciała i poczucie atrakcyjności fizycznej są ważne dla poziomu satysfakcji seksualnej kobiet (P u jols i in., 2010). Współcześnie obowiązujący w seksuologii model reakcji seksualnej autorstwa Rosemary B a s s on (2005) zakłada, że wysoka samoocena jest jednym $\mathrm{z}$ istotnych psychologicznych warunków uzyskiwania satysfakcji seksualnej, a chęć utrzymania bądź podnoszenia poziomu samooceny i atrakcyjności fizycznej - częstym, pozaseksualnym motywem angażowania się w aktywność seksualną.

\section{Badania empiryczne}

Rezultaty dotychczasowych badań (m. in. wyżej wymienionych) pozwalają na sformułowanie przypuszczenia o związku satysfakcji seksualnej i samooceny z poczuciem jakości życia. Celem prezentowanych poniżej badań było:

- zdiagnozowanie poziomu satysfakcji seksualnej wśród młodych dorosłych,

- określenie korelatów satysfakcji seksualnej (związków z samooceną i poczuciem jakości życia).

Przewidywano, że wysoki poziom satysfakcji seksualnej i samooceny pozostaje w związku z wysokim poziomem poczucia jakości życia zarówno wśród kobiet, jak i mężczyzn.

Satysfakcja seksualna rozumiana jest przez autorki jako ustosunkowanie podmiotu (poznawczo-emocjonalne) do własnej atrakcyjności seksualnej i podejmowanej aktywności seksualnej.

Poczucie jakości życia rozumiane jest, zgodnie z koncepcją M. Strás-Romanowskiej (2005), jako ocena poznawcza i uczucia towarzyszące określonemu sposobowi życia, na który składają się relacje, rodzaje przeżyć, działania i rozwój.

W koncepcji tej wyróżnia się cztery wymiary jakości życia - biologiczny, społeczny, podmiotowy i metafizyczny. 
Sfera psychofizyczna odnosi się do biologicznego dobrostanu (zdrowia). Zakłóceniem tej sfery może być choroba. Poczucie zadowolenia $\mathrm{w}$ tej sferze związane jest $\mathrm{z}$ zaspokajaniem potrzeb natury biologicznej i aktywnością życiową pozostającą $\mathrm{w}$ zgodzie ze swoim organizmem.

Sfera psychospołeczna. Poczucie jakości życia w tym wymiarze odnosi się do uczestnictwa człowieka w życiu społecznym - podejmowania ról społecznych i realizacji standardów społecznych. Do osiagania wysokiej jakości życia w tym obszarze przyczynia się odczuwanie miłości, akceptacji, przynależności i szacunku ze strony innych ludzi. Zaburzenie tej sfery może stanowić poczucie samotności.

Sfera podmiotowa dotyczy podmiotowości człowieka, a wyrażana jest w poczuciu indywidualności, ponoszeniu odpowiedzialności za swoje życie, realizowaniu swoich celów i poczuciu bycia autentycznym, „w zgodzie ze sobą”.

Sfera metafizyczna odnosi się do wymiaru duchowego. Stanowi akceptację i realizację wartości, które są ponadczasowe i uniwersalne. Łączona jest z poczuciem sensu życia, przeżyciami religijnymi, dążeniem do autotranscendencji poprzez akceptację i realizację wartości uniwersalnych (dobro, prawda, piękno, miłość).

W badaniach uczestniczyło 100 osób (49 kobiet i 51 mężczyzn) w wieku od 23. do 35. roku życia, pozostających w nieformalnym, bezdzietnym związku przynajmniej od roku, aktywnych zawodowo, z wykształceniem wyższym i wyższym niepełnym.

T a b e la 1

Moc dyskryminacyjna pytań

\begin{tabular}{|c|c|c|c|c|c|c|c|c|c|c|}
\hline Numer pytania & 1 & 2 & 3 & 4 & 5 & 6 & 7 & 8 & 9 & 10 \\
\hline $\begin{array}{c}\text { Korelacja } r \text { - } \\
\text {-Pearsona }\end{array}$ & 0,675 & 0,449 & 0,589 & 0,583 & 0,692 & 0,654 & 0,715 & 0,603 & 0,649 & 0,637 \\
\hline $\begin{array}{c}\text { Istotność } \\
\text { (dwustronna) }\end{array}$ & 0,001 & 0,001 & 0,001 & 0,001 & 0,001 & 0,001 & 0,001 & 0,001 & 0,001 & 0,001 \\
\hline
\end{tabular}

Źr ódł o: opracowanie własne.

Konfirmacyjna analiza czynnikowa

\begin{tabular}{|c|c|c|c|}
\hline RMSEA & LO 90 & HI 90 & PCLOSE \\
\hline 0,073 & 0,001 & 0,133 & 0,289 \\
\hline
\end{tabular}

RMSEA - średniokwadratowy błąd aproksymacji; $L O 90$ - dolna granica przedziału ufności; HI 90 - górna granica przedziału ufności; PCLOSE - poziom istotności $p$ dla hipotezy zerowej (dla $\left.\mathrm{H}_{0} p \leq 0,05\right)$.

Źr ó dło: opracowanie własne. 
W celu dokonania pomiaru zmiennych zastosowano następujące metody: Kwestionariusz Poczucia Jakości Życia M. Straś-Romanowskiej i in. (Frą c k ow i a k, 2004), Skalę Samooceny SES autorstwa M. Rosenberga w adaptacji I. Dzwonkowskiej, K. Lachowicz-Tabaczek i M. Łag uny (2008), a także Kwestionariusz Satysfakcji Seksualnej G. Dolińskiej-Zygmunt i A. Domejko. Zawiera on dziesięć twierdzeń, obejmujących dwa obszary (zgodnie z przyjętą definicją satysfakcji seksualnej): własną atrakcyjność seksualną i podejmowaną aktywność seksualną. Osoba badana ustosunkowuje się do nich za pomocą czterostopniowej skali Likerta. W celu zachowania trafności teoretycznej zastosowano: metodę sędziów kompetentnych, analizę mocy dyskryminacyjnej pytań (tab. 1) i konfirmacyjną analizę czynnikową (tab. 2). Pominięto $\mathrm{w}$ dalszych analizach i postanowiono usunąć z kwestionariusza te pytania, które wykazywały mniejszą moc dyskryminacyjną niż 0,4 . Zredukowano również pytania o część tych, pomiędzy którymi występowała istotna dwustronna korelacja Pearsona, zakładając, że mogą być do siebie zbyt podobne i nieść taką samą treść. Konfirmacyjna analiza czynnikowa wykazała istnienie jednego czynnika. Do oceny dopasowania modelu użyto wskaźnika RMSEA, który wyniósł 0,073 (tab. 2). Rzetelność metody mierzona $\alpha$-Cronbacha świadczy o wysokiej spójności testu, gdyż wynosi 0,83 . Teoretyczny rozkład wyników zawiera się $\mathrm{w}$ przedziale $(10 ; 40)$.

\section{Wyniki}

Satysfakcja seksualna. Wśród badanych osób dominuje zadowolenie z życia seksualnego (średnia wyników wyniosła 33,71). Analiza testem $t$-Studenta wykazała, iż różnica pomiędzy płciami w średnich wartościach satysfakcji seksualnej nie jest istotna statystycznie.

T a b e la 3

Średni wynik poczucia jakości życia osób badanych (wynik globalny i poszczególne sfery)

\begin{tabular}{|l|c|c|}
\cline { 2 - 3 } \multicolumn{1}{c|}{} & $\begin{array}{c}\text { Badania } \\
\text { własne }\end{array}$ & $\begin{array}{c}\text { Badania M. Straś- } \\
\text {-Romanowskiej } \\
\text { (za: F r ą c k o w i a k, 2004) }\end{array}$ \\
\hline Średni wynik globalny & 185,38 & 191,4 \\
\hline Sfera podmiotowa & 46,66 & - \\
\hline Sfera psychofizyczna & 47,37 & - \\
\hline Sfera psychospołeczna & 47,67 & - \\
\hline Sfera metafizyczna & 46,75 & - \\
\hline
\end{tabular}

Źr ód ło: opracowanie własne. 
Poczucie jakości życia. Rozkład liczebności wskazuje na dominację przeciętnego poziomu zadowolenia z życia wśród osób badanych. Średnie wyniki uzyskane przez osoby badane $\mathrm{w}$ zakresie globalnej oceny i poszczególnych sferach poczucia jakości życia przedstawiono $\mathrm{w}$ tab. 3. Analiza testem $t$-Studenta wykazała, iż różnica pomiędzy płciami w średnich wartościach globalnego poczucia jakości życia i jego sfer nie jest istotna statystycznie.

Samoocena. Średnia wyników $(30,48)$ wskazuje na pozytywną samoocenę $\mathrm{w}$ badanej grupie. Analiza testem $t$-Studenta wykazała, iż różnica między płciami w zakresie średnich wyników nie jest istotna statystycznie.

\section{Związek satysfakcji seksualnej z poczuciem jakości życia}

Współczynnik $r$-Pearsona korelacji zmiennych satysfakcja seksualna i globalne poczucie jakości życia $(r=0,453 ; p<0,001)$ wskazuje na istotną statycznie, ale umiarkowaną, zależność (tab. 4). Analiza zależności satysfakcji seksualnej z poszczególnymi wymiarami poczucia jakości życia wskazała na istnienie istotnych statystycznie związków między zmiennymi, ale najsłabsze okazały się związki satysfakcji seksualnej ze sferami: psychospołeczną i metafizyczną.

Korelacja Pearsona między satysfakcją seksualną a poczuciem jakości życia i jego wymiarami

\begin{tabular}{|l|c|}
\hline Sfera psychofizyczna & $0,533^{* *}$ \\
\hline Sfera psychospołeczna & $0,243^{*}$ \\
\hline Sfera podmiotowa & $0,310^{* *}$ \\
\hline Sfera metafizyczna & $0,262^{* *}$ \\
\hline Wynik globalny poczucia jakości życia & $0,453^{* *}$ \\
\hline
\end{tabular}

* Korelacja jest istotna na poziomie 0,05 (dwustronnie).

** Korelacja jest istotna na poziomie 0,001 (dwustronnie).

Ź r ódło: opracowanie własne.

Ciekawych wyników dostarczyło międzypłciowe porównanie siły korelacji satysfakcji seksualnej oraz poczucia jakości życia i jego poszczególnych sfer. W przypadku kobiet satysfakcja seksualna wiąże się w sposób istotny zarówno z wynikiem globalnym, jak i wszystkimi sferami poczucia jakości życia. Analiza wyniku korelacji w grupie mężczyzn wskazuje na związek satysfakcji seksualnej jedynie $z$ wynikiem globalnym i sferą psychofizyczną. Korelacja satysfakcji seksualnej z poczuciem jakości życia i jego sferami jest silniejsza w przypadku kobiet (tab. 5). 
Korelacja Pearsona między satysfakcją seksualną a poczuciem jakości życia i jego wymiarami w zależności od płci

\begin{tabular}{|l|l|c|}
\cline { 2 - 3 } \multicolumn{1}{c|}{} & Kobiety & Męźczyźni \\
\hline Sfera psychofizyczna & $0,588^{* *}$ & $0,477^{* *}$ \\
\hline Sfera psychospołeczna & $0,456^{* *}$ & 0,005 \\
\hline Sfera podmiotowa & $0,365^{* *}$ & 0,239 \\
\hline Sfera metafizyczna & $0,378^{* *}$ & 0,113 \\
\hline $\begin{array}{l}\text { Wynik globalny poczucia } \\
\text { jakości życia }\end{array}$ & $0,567^{* *}$ & $0,304 *$ \\
\hline
\end{tabular}

* Korelacja jest istotna na poziomie 0,05 (dwustronnie).

** Korelacja jest istotna na poziomie 0,001 (dwustronnie).

Ź ró dło: opracowanie własne.

Przeprowadzono również analizę korelacji pomiędzy satysfakcją seksualną i samooceną. Wynik potwierdził przypuszczenie o istnieniu pomiędzy nimi związku - współczynnik korelacji wyniósł 0,44 przy $p<0,001$. Pomiędzy kobietami i mężczyznami nie ma różnic w zakresie siły związku tych zmiennych.

Współczynnik korelacji $r$-Pearsona pomiędzy samooceną a globalnym wynikiem poczucia jakości życia $(r=0,621 ; p<0,001)$ i jego sferami: podmiotową, psychospołeczną, psychofizyczną wskazuje na istotny silny związek pomiędzy zmiennymi (tab. 6). Różnice międzypłciowe w sile korelacji nie są istotne statystycznie. W przypadku mężczyzn istnieje korelacja pomiędzy samooceną a sferą metafizyczna, ale jest ona słaba.

\section{Tabe la 6}

Korelacja Pearsona między samooceną a poczuciem jakości życia i jego wymiarami

\begin{tabular}{|l|l|}
\hline Sfera psychofizyczna & $0,556^{* *}$ \\
\hline Sfera psychospołeczna & $0,512^{* *}$ \\
\hline Sfera podmiotowa & $0,514^{* *}$ \\
\hline Sfera metafizyczna & $0,278^{*}$ \\
\hline $\begin{array}{l}\text { Wynik globalny poczucia jakości } \\
\text { życia }\end{array}$ & $0,621^{* *}$ \\
\hline
\end{tabular}

* Korelacja jest istotna na poziomie 0,05 (dwustronnie).

** Korelacja jest istotna na poziomie 0,001 (dwustronnie).

Ź r ó dło: opracowanie własne. 
Analiza regresji dla zmiennej zależnej poczucie jakości życia i zmiennych niezależnych satysfakcja seksualna z życia i samoocena

\begin{tabular}{|l|c|c|c|c|c|}
\hline \multirow{2}{*}{ Model } & \multicolumn{2}{|c|}{$\begin{array}{c}\text { Współczynniki } \\
\text { niestandaryzowane }\end{array}$} & $\begin{array}{c}\text { Współczynniki } \\
\text { standaryzowane }\end{array}$ & \multirow{2}{*}{$t$} & \multirow{2}{*}{$p$} \\
\cline { 2 - 4 } & $B$ & $S D$ & $\beta$ & & \\
\hline Stała & 113,838 & 8,975 & - & 12,684 & 0,001 \\
\hline Satysfakcja seksualna & 0,713 & 0,267 & 0,223 & 2,670 & 0,009 \\
\hline Samoocena & 1,446 & 0,262 & 0,473 & 5,523 & 0,001 \\
\hline
\end{tabular}

Źró dło: opracowanie własne.

W celu udzielenia odpowiedzi na pytanie, czy satysfakcja seksualna i samoocena są predyktorami poczucia jakości życia, zastosowano analizę regresji (tab. 7). Wynik analizy potwierdził przypuszczenie, że im wyższy poziom samooceny i satysfakcji seksualnej, tym wyższy poziom poczucia jakości życia. Obie wprowadzone do równania zmienne są predyktorami globalnego wyniku poczucia jakości życia i pozwalają przewidywać jego poziom. Silniejsza zależność z poczuciem jakości życia $(\beta=0,47 ; p<0,001)$ cechuje samoocenę. Im wyższa samoocena badanych, tym wyższe poczucie jakości ich życia. Drugim w kolejności predyktorem jest satysfakcja seksualna $(\beta=0,22$; $p<0,05)$. Można wnioskować, że im wyższe zadowolenie z życia seksualnego, tym wyższe poczucie jakości życia badanych. Okazało się również, że samoocena jest predyktorem jakości życia w sferze podmiotowej, psychospołecznej i psychofizycznej, a satysfakcja seksualna jest silnym predyktorem poczucia jakości życia w sferze psychofizycznej.

\section{Wnioski}

Biorących udział w badaniu młodych dorosłych cechowały średni poziom poczucia jakości życia, pozytywna samoocena i zadowolenie z życia seksualnego. Przeprowadzone badania wykazały istotne związki satysfakcji seksualnej z samooceną, a także obu zmiennych z poczuciem jakości życia - im wyższy poziom samooceny i satysfakcji seksualnej badanych, tym wyższy poziom poczucia jakości ich życia.

Wbrew stereotypom, zadowolenie z seksualnego wymiaru życia jest silniej związane z poczuciem jakości życia kobiet zarówno w przypadku jego globalnej oceny, jak i poszczególnych sfer. W grupie mężczyzn satysfakcja seksualna wiąże się $\mathrm{z}$ oceną globalną $\mathrm{i}$ jedynie $\mathrm{z}$ psychofizycznym wymiarem poczucia 
jakości życia. Uzyskane rezultaty badawcze potwierdzają współczesne stanowisko seksuologów, według którego satysfakcja seksualna kobiet warunkowana jest nie tyle przez fizykalne zmiany zachodzące w ciele, co czynniki psychologiczne. Niezwykle istotny jest dla kobiet szerszy kontekst - sytuacyjny, społeczny, psychiczny (Nowosielski, 2010). To właśnie kontekst decyduje o rozpoznaniu i zinterpretowaniu pobudzenia jako seksualnego (L e w-S ta ro w i c z, 2010). Cyrkularny model kobiecej seksualności, zaproponowany przez R. B a s s on (2005), zakłada, że przyjemność fizyczna ze współżycia i rozładowanie potrzeby seksualnej są tyko jednymi z wielu powodów podejmowania aktywności seksualnej. Szczególnie ważne, a czasami nawet ważniejsze niż fizjologiczna przyjemność, są dla kobiet: poczucie intymności, satysfakcja emocjonalna, poczucie atrakcyjności i zadowolenie ze związku, które mogą być budowane i umacniane poprzez seks. Zdarza się, że kobiety podejmują aktywność seksualną $\mathrm{w}$ celu zaspokojenia powyższych potrzeb, w tym podniesienia samooceny, gdy pożądanie i podniecenie nie występują. Wynik badania uzyskany w grupie kobiet można zinterpretować dwojako. Po pierwsze, dla kobiet kontekst może mieć zdecydowanie silniejszy wpływ na możliwość czerpania satysfakcji z seksu i seksualności niż ma to miejsce u mężczyzn, a więc poza sferą psychofizyczną dla oceny jakości życia seksualnego istotna będzie również ocena podmiotowej, psychospołecznej i metafizycznej sfery życia. Po drugie, wysoki poziom satysfakcji seksualnej może podnosić zadowolenie z innych wymiarów życia, $\mathrm{m}$. in. takich jak relacje interpersonalne lub też stosunek do samej siebie (poczucie atrakcyjności, poczucie własnej wartości, poczucie zdrowia).

Zgodnie z przewidywaniami, poziom samooceny jest istotnym predyktorem poziomu poczucia jakości życia dla obu płci. Możliwe, że osoby o wysokiej samoocenie deklarują wyższe poczucie jakości swojego życia ze względu na specyfikę oceny informacji, które do nich docierają. Osoby o wysokiej samoocenie przetwarzają docierające informacje jako podtrzymujące lub podnoszące jej poziom. Stosują one więcej strategii poznawczych, aby tworzyć swój pozytywny wizerunek, są odważne i traktują nowe sytuacje jako pozytywne wyzwania czy szanse. Osoby o samoocenie niskiej zachowują się odwrotnie, ostrożnie oceniając dopływające do nich informacje i zachowawczo podchodząc do nowych sytuacji. Ich priorytetem jest nie podnoszenie, ale utrzymanie obecnego poziomu samooceny. Być może dlatego też osoby o samoocenie wysokiej oceniają wyżej swoje życie i są dumne ze swoich osiągnięć, natomiast osoby o samoocenie niskiej oceniają je powściagliwie (T r a w k a, 2005).

Przedstawione badania wskazują na satysfakcję seksualną i samoocenę jako istotne wskaźniki globalnej oceny jakości życia młodych dorosłych. Problem ten zdecydowanie wymaga dalszych dociekań i ustaleń empirycznych. Autorki kontynuują badania zarówno w obszarze uwarunkowań satysfakcji seksualnej, jak i jej implikacji dla jakości życia i zdrowia. 


\section{Bibliografia}

A r r ingt o n R., C o fra n c e s J., W u A. (2004), Questionnaires to measure sexual quality of life, „Quality of Life Research”, 13, 1643-1658,

B a n c r o ft J. (2009), Seksualność człowieka, Elsevier Urban \& Partner, Wrocław.

B a s s o n R., B rot to L., L a a n E., R e d m ond G., U t i a n W. (2005), Assessment and Management of Women's Sexual Dysfunctions: Problematic Desire and Arousal, „Journal of Sex Medicine", 2, 291-300.

B a ume is te r R., Campbe 11 J., Krueger J., Voh K. (2003), Does high self-esteem cause better performance, interpersonal success, happiness, or healthier lifestyles?, „Psychological Science in the Public Interest", 4 (1), 1-44.

C a me r o n J., S t in s o n A., G a e t z R., B a i c h e n S. (2010), Acceptance is in the Eye of the Beholder: Self-Esteem and Motivated Perceptions of Acceptance from the Opposite Sex, „Journal of Personality \& Social Psychology”, 99 (3), 513-530.

Doliński D., Kofta M. (2006), Poznawcze podejście do osobowości, [w:] J. Strela u (red.), Psychologia. Podręcznik akademicki, t. II, GWP, Gdańsk.

D z w o n k ow s k a I., L a c how i c z - T a b a c z e k K., Ła g u n M. (2008), Samoocena i jej pomiar. Polska adaptacja SES M. Rosenberga. Podręcznik, Pracownia Testów Psychologicznych, Warszawa.

F rąc kow i a k T. (2004), Personalistyczno-egzystencjalna koncepcja poczucia jakości życia. Próba operacjonalizacji, Uniwersytet Wrocławski, Wrocław, praca magisterska.

Gulczyńska A., Jankowiak B. (2006), Zwiqzek poczucia koherencji z wybranymi aspektami seksualności studentów, „Seksuologia Polska”, 4 (1), 6-12.

L e i b 1 u m S., R o s e n R. (2005), Terapia zaburzeń seksualnych, GWP, Gdańsk.

Lew-Starowicz Z. (2010), Zdrowie seksualne kobiet, [w:] Z. Lew-Starowicz, V. S k r z y p u l e c (red.), Podstawy seksuologii, PZWL, Warszawa, 122-133.

Li Ho Ch. W., Chan Siu L. P., Chung Oi K. J., Chui Miu L. M. (2010), Relationships among mental health, self-esteem and physical health in Chinese adolescents: An exploratory study, ,Journal of Health Psychology”, 15 (1), 96-106.

$\mathrm{N}$ arvae z-R ehbein R., Garcia-Vazquez E., Madson L. (2006), The relation between self-esteem and sexual functioning in collegiate woman, „The Journal of Social Psychology", 146 (2), 250-252.

N o w o s i e ls k i K. (2010), Fizjologia reakcji seksualnej kobiet, [w:] Z. L e w-S t a r o w i c z, V. S k r z y p u l e c (red.), Podstawy seksuologii, PZWL, Warszawa.

$\mathrm{Puj}$ ols Y., S e a 1 B. N., M e s t o n C. M. (2010), The association between sexual satisfaction and body image in women, „The Journal Of Sexual Medicine”, 7 (2), 905-916.

Rosen C., B a chmann G. (2008), Sexual Well-Being, Happiness, and Satisfaction, in Women: The Case for a New Conceptual Paradigm, „Journal of Sex \& Marital Therapy”, 34, 291-297.S a $1 \mathrm{~m}$ e 1 a-A ro

S a 1 m e la-A r o K., N u r m i J. (2007), Self-Esteem during University Studies Predicts Career Characteristics 10 Years Later, „Journal of Vocational Behavior”, 70 (3), 463-477.

Trawka K. (2005), Samoocena, afekt i nastrój jako wyznaczniki poczucia jakości życia, „Psychologia Jakości Życia”, 5 (1), 1-23.

V e n t e g o d t S. (1998), Sex and the quality of life in Denmark, „Archives of Sexual Behavior”, 27 (3), 295-307.

W oj c is z ke B. (2006), Człowiek wśród ludzi. Zarys psychologii społecznej, Wydawnictwo Naukowe Scholar, Warszawa. 
Grażyna Dolińska-Zygmunt, Agnieszka Nomejko

\section{Sexual satisfaction and self-esteem in relation to a sense of quality of life}

Numerous studies have shown that sexual satisfaction and self-esteem are strongly related and that they significantly condition a sense of quality of life. The article presents the results of the authors study, which aim was to establish the relation between sexual satisfaction, self-esteem and sense of quality of life for people in they early adulthood.

The study sample consisted of 51 men and 49 women aged from 23 to 35 years old, employed and remain in childless informal relationships since at least one year. The Questionnaire of Sexual Satisfaction (author's method), Self-Esteem Scale by M. Rosenberg and the Questionnaire of Quality of Life by M. Straś-Romanowska were used in the measurement.

Results indicate that sexual satisfaction and self-esteem are related and they are predictors of the sense of quality of life. Self-esteem is associated significantly with the global assessment of quality of life and its various spheres - psychophysical, psychosocial, subjective, metaphysical. There is also significant correlation between sexual satisfaction and sense of quality of life. It turned out that there is a significant sex difference between the strength of correlation between sexual satisfaction and the global quality of life and its various spheres. Contrary to stereotypes, this relationship is stronger in women.

Keywords: sexual satisfaction, self-esteem, quality of life (satysfakcja seksualna, samoocena, jakość życia). 